\title{
ANALYSIS OF THE EFFECT OF PERSONALITY, TRANSFORMATIONAL LEADERSHIP, JOB ENGAGEMENT, ON PERFORMANCE WITH ORGANIZATIONAL COMMITMENT AND ORGANIZATIONAL CITIZENSHIP BEHAVIOR AS MEDIATING VARIABLES OF SECRETARY OF PRIVATE COMPANIES IN SURABAYA
}

\author{
H.Teman Koesmono \\ Lecturer Faculty of Business, Widya Mandala Catholic University ,Surabaya, East Java-Indonesia
}

\begin{abstract}
This study is to analyze the Influence of Personality, Transformational Leadership, Job Engagement, on Performance with Mediating Variables Organizational Commitment and Organizational Citizenship Behavior Secretary of Private Company Offices in Surabaya. The results of the study are. Personality, Transformational Leadership, Job Engagement, affect Performance. Organizational Commitment has an effect on Organizational Citizenship Behavior while Organizational Citizenship Behavior has a significant effect on performance. The results of this study can illustrate how important the behavioral variables possessed by a company secretary so that the results of their performance can be relied upon because of their strategic position as holders of confidential information data material for the company.
\end{abstract}

Keywords: Personality, Transformational Leadership, Job Engagement, Organizational Commitment, Motivation, Organizational Citizenship Behavior, Organizational Culture and Performance

DOI: $10.7176 / \mathrm{IKM} / 9-5-05$

Publication date:May $31^{\text {st }} 2019$

\section{Background}

The function of the administrative executor in the company has a strategic position for the orderliness of all data owned by the company both external and internal data between the parts that are inside the company. Data owned by the company can be either hard copy or soft copy depending on the needs. Orderly administration is the main demand for all activities of an organization or company that are either oriented to profit motives or non profit motives. If the administration of the company is inaccurate and orderly, it will have a direct impact on the company's operations because the company does not have accurate data on the activities that have been carried out or will be carried out in accordance with the Standard Operating Procedure (SOP) that it already has. In order for companies to always have an orderly administrative climate that is reliable, we need an individual figure who runs the administrative operations seriously and can be accounted for the completeness of the data and confidentiality. It is not uncommon for us to find difficulties when searching for organization or company data when it is needed immediately to make a decision about the problem it is facing. The figure of the person who handles secretariat must be able and have sufficient Knowledge, Skills and Attitudes, Personality (Knowledge, Skill and Attitude, personality) to carry out their duties so that the data that will be used as information for management and outside the company is always ready to be presented if needed. Of course there must also be facilities and infrastructure that support managing data as information material both in the form of software and hardware. Especially for office administration managers need a qualified personality because it will have an impact on their behavior which is sometimes needed by the leadership to be able to support management in any condition regarding readiness to present good and correct data and accurate in decision making. A person's personality will be reflected in his behavior in various tasks and responsibilities, the smarter a person's personality, the tendency of his performance behavior always leads to high personal discipline in maintaining the success of his duties in accordance with his job description.

According to Moorhead and Griffin (2010: 63) personality is a series of psychological attributes that are relatively stable and distinguish between people from one another. Given the personal character of one person to another may be different then, of course in the style of behavior will vary too depending on the environment in which the person concerned is located. In carrying out their respective duties, of course, someone needs a person as the coordinator of the activity which is their responsibility. The coordinator is a leader who accommodates all activities under his leadership. There are various types of leadership styles, one of which is transformational leadership which has the task of transforming all of its needs and wants to its followers so that the organization can achieve its stated goals in accordance with its work plan. Hughes et al (2010: 5) leadership is a process when a boss encourages his subordinates to behave according to his wishes. As described above, an officer must obtain 
support from an organization or company so that the operational duties can run smoothly, therefore the role of the organization can also contribute directly to the secretarial operations of the office so that its data is guaranteed. and employees can express their abilities to the maximum. both in terms of emotions and their high motivation in carrying out their duties and obligations. Bakker (2010) Job Engagement includes emotional conditions and active feelings of someone in carrying out their own efforts to achieve their goals. Every employee will have the feeling to assess the existence of an organization or company, is it able to provide confidence to employees so that they have a sense of loyalty to the company and it is not easy to move to another place by considering the advantages and disadvantages of having other plans in their career. Robbins and Judge (2015: 47) organizational commitment is the level to which an employee sits with an organization and its goals and desires to maintain its membership in the organization. A person's organizational commitment will be even greater if the personality factors that are owned support the maturity in making decisions and leadership of someone will also give encouragement to someone to remain in the company accompanied by a strong will to carry out their feelings to do more for the organization with high enthusiasm. Along with the organizational commitment that is owned by someone or the person concerned will be willing and willing to do anything outside of his duties and feel capable of carrying out tasks outside the main task. Robbins and Judge (2015: 53) Organizational Citizenship Behavior is the organization of positive behavior from someone who is willing to help the work of others in the hope of exceeding normal performance in his work. How strong organizational behavior can help create citizenship behavior (OCB), the motivational variables that exist within the organization or company will be the moderator variable which makes the influence of organizational commitment on OCB stronger or not.

According to Kreitner and Kinicki (2014: 212) motivation is a psychological process that provides stimuli and directs behaviors that have goals. Obviously OCB will have an effect on someone's performance at the end of their activities because OCB is a distinctive advantage of efforts made in the interest of the organization to achieve the shared goals that have been owned. Along with the high willingness to carry out activities regardless of whether the activities concerned responsibility or not will result in high performance in addition to organizational culture factors can make the moderator influence OCB on one's performance. According to Koesmono (2016: 117), Work culture is a behavioral guide for employees when carrying out their work activities to lead to goals and objectives in the production process so that the results reach the maximum point as expected by the stakeholders both in quality and quantity. Maximum performance is the hope of all parties so that it requires a hard effort to achieve it and even period after period of performance is expected to show a high surge in any conditions. Whereas McShane and Glinow (2003: 448) organizational culture is the basic pattern of share assumptions, values and beliefs is considered to be the correct way of thinking about and acting on problems and opportunities facing organizations. According to Rahmawati (2008: 123) performance is the result of one's business in a certain period of time when carrying out their duties. Given the importance of office secretaries in private companies as data managers of companies or organizations it is necessary to conduct research on variables that can affect their performance on the topic: Effect Analysis of Personality, Transformational Leadership, Job Engagement, on Performance with Mediating Variables Organizational Commitment and Organizational Citizenship Behavior of Secretary of Private Company Offices in Surabaya.

\section{Theoritical Review}

For a secretary who handles corporate administration is a party that is strongly associated with data owned by the company, given the importance of the position it has, it must have resilience in managing corporate documents both short and long term. Company data must be as real as what is needed by management because with an orderly administration, it is possible for the company not to experience problems if it requires data relating to its operations. For a company secretary requires a strong personality in an effort to maintain company data both internal data and external data. Personality is a statement of the form of tendency of one's behavior on the basis of the framework of his mindset. McShane and Glinov (2003: 84) Personality is a realavely stable pattern of behaviors and consistent internal states that explain personal behavioral tendencies. The more perfect a person's personality will strengthen his commitment to the organization. Abdullah et al (2013) Personality Significant Effect to Organizational Commitment and Employee performance. Personality can have a significant impact on organizational commitment and employee performance. It is understandable that one's personality is an identity of identity so that it will have an impact on loyalty and performance to the organization. A person's leadership will have an impact on his followers and if his leadership feels comfortable for his followers it will have an impact on organizational commitment. Seed et al (2013) Transformational Leadership significant influence to Organizational commitment of employees'. Gathungu et al (2015) Transformational Leadership has a direct influence on Organizational Citizenship behavior and job performance. In the study of Sani and Maharani (2012) found that Transformational Leadership and Organizational Commitment, Organizational Citizenship behavior direct effect to Job Performance. Whereas Bakker (2010) Job engagement is an active representation of emotions and feelings towards work activities carried out by someone. 
According to Shamaa et al (2015), Work engagement positive Influence on Organizational commitment. When a person has a high emotional attachment to his work, it will have an impact on his organizational commitment, therefore the existence of organizational commitment must be maintained so that employee loyalty becomes higher and not easily shaken and wants to leave the company. Robbins and Judge (201547) organizational commitment is the level where some workers identify an organization, its goals and expectations to remain a member. Regarding the Organizational Commitments held by employees it will have an impact on Organizational Citizenship Behavior (OCB). Robbins and Judge (2015: 19) Citizenship behavior is the formal behavior of workers in the psychological and social environment that exceeds their responsibilities and gives performance above expectations. Not everyone will contribute OCB to the organization and strong people will run it for maximum performance from the efforts made. High OCB awareness will produce maximum performance for the organization. Whereas Monday (2008: 259) the performance of the results of the employee's work is in accordance with the target of his work in the period underwent. While performance management is a process that is oriented and directed at the goal of maximizing the productivity of employees, teams and organizations. Whatever form of performance is expected in the organization will lead to the maximum achievement of the performance of organizational actors both at the strategic and non-strategic levels on all fronts. A person's motivation will strengthen the position of his organizational commitment in creating or influencing his Organizational Citizenship Behavior. McShane and Glinov (2003: 33) Motivation is the forces within a person that influences his or her direction, intensity and persistence of voluntary behavior. Organizational culture as a guideline for the behavior of individuals in running an organization will also influence the strength or lack of citizenship behavior (OCB) in influencing the performance of employees, because whatever OCB is good but if it is not supported by a good and true organizational culture performance will not be as expected. Organizational culture will place someone to behave according to what is expected by the stakeholder of the company.

\subsection{Research Conceptual Framework}

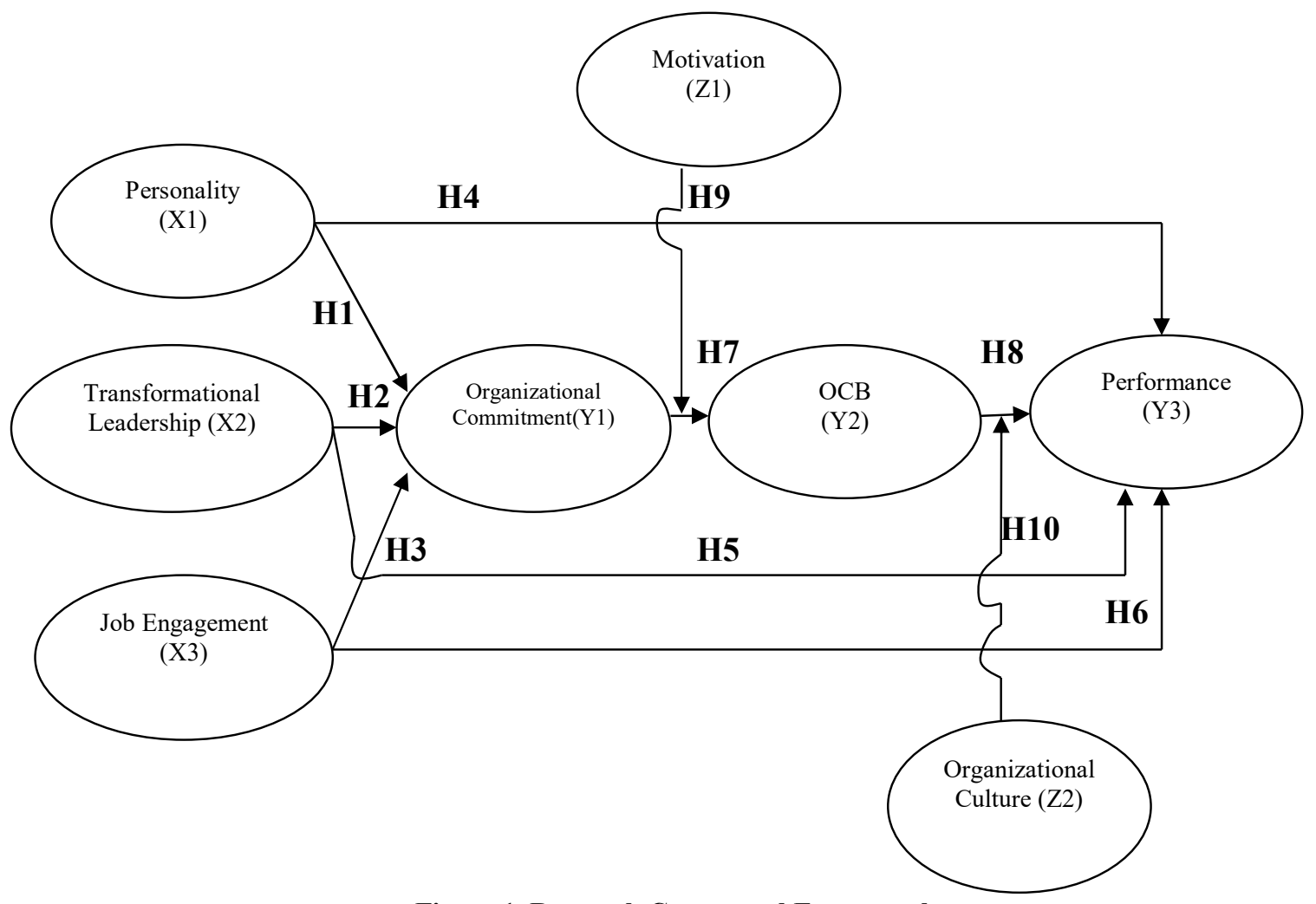

Figure 1. Research Conceptual Framework

\subsection{Hypotheses}

Hypotheses of this research are described as follow 
1. Personality affects the Organizational Commitment of the Secretary of the Private Company Office in Surabaya

2. Transformational Leadership influences Organizational Commitment Secretary of Private Enterprise Office in Surabaya

3. Job Engagement affects the Organizational Commitment of the Private Company Office Secretary in Surabaya

4. Personality influences the performance of the Secretary of the Private Company Office in Surabaya

5. Transformational Leadership influences the Performance of Secretaries of Private Company offices in Surabaya

6. Job Engagement affects the performance of the Secretary of the Private Enterprise Office in Surabaya

7. Organizational commitment has an effect on OCB Secretary of the Private Enterprise Office in Surabaya

8. OCB affects the Performance of the Secretary of the Private Company Office in Surabaya

9. Motivation as a variable Moderator influences Organizational Commitment to OCB Secretary of Private Company Offices in Surabaya

10. Organizational Culture as a moderator variable of the influence of OCB on the Performance of the Secretary of the Private Company Office in Surabaya

\section{Research Method}

\subsection{Research Design}

Based on the background of the problem it can be classified that this study uses a hypothesis. This research is based on current facts or conditions from the secretary of a Private Company in Surabaya. This study presents the Analysis of the Influence of Personality, Transformational Leadership, Job Engagement, on Performance with Mediating Variables Organizational Commitment and Organizational Citizenship Behavior of the Office of Private Companies in Surabaya.

\subsection{Data types and sources}

Data type is interval scale (likert scale) indicated by the same distance between numbers one with the other starting from the smallest to the largest number, namely 1 (strongly disagree), 2 (disagree), 3 (neutral), 4 (agree) and 5 (strongly agree). While the data source used is primary by distributing questionnaires to respondents

\subsection{Sampling technique and number of sample}

The sampling technique used was random sampling from the private company secretary population in Surabaya. Sugiyono (2010: 91) Adequacy of the number of samples used is 100-200 people, or the number of samples = Number of indicators X 5 to 10 . In this study circulating questionnaires that returned 250 sheets and meet the requirements of 188 sheets

\subsection{Data Analysis Technique}

Technical data analysis will be used using SEM (Structural Equation Modeling) with the AMOS 4.0 Program. Ferdinand (2014: 110)

Regression Equation

$\mathrm{Y} 1=\mathrm{aX} 1+\mathrm{bX} 2+\mathrm{cX} 3$

$\mathrm{Y} 2=\mathrm{dY} 1$

$\mathrm{Y} 3=\mathrm{eX} 1+\mathrm{fX} 2+\mathrm{gX} 3+\mathrm{hY} 2$

$\mathrm{Z} \quad=$ Moderating variable

\subsection{Variables Identification}

1. Independent variables: Personality (X1), Transformational Leadership (X2), Job Engagement (X3)

2. Dependent variables: Organizational Commitment (Y1), Organizational Citizenship Behavior (Y2), Performance (Y3)

3. Moderating variable: Motivation (Z1) and Organizational Culture (Z2)

\subsection{Definition of Variables}

1. Personality is the whole way in which an individual reacts and interacts with other individuals 
2. Transformational leadership is the process of someone in leading other people to inspire followers in the direction of their stated goals by clarifying their roles and duties.

3. Job Engagement is the response of employees psychologically (emotional) and intellectually to work tasks with high enthusiasm

4. Organizational Commitment is the degree to which an employee ties himself to the organization and his desire to achieve goals and maintain membership in the organization.

5. Organizational Citizenship Behavior is the willingness of someone to do organizational activities outside of their main tasks.

6. Performance is someone's achievement in a certain period of time in carrying out his work activities

7. Motivation is an encouragement both internally and externally to a person to achieve what is needed and desired

8. Organizational Culture is a code of conduct and social glue in carrying out activities within the organization

\section{Results}

\subsection{Descriptive Statistics}

Respondents:

The sex of the respondent is female

Age of Respondents:

20-25 years: 80 people

26-30 years: 64 people

$>30$ years: 44 people

Education Respondents

Middle School: 110 people

Vocational Program: 45 people

Undergraduated: 33 people

Work experience

1-5 years: 40 people

5 - 10 Years: 85 people

10-15 years: 35 people

$>15$ years: 28 people

\subsection{Description of Research Results}

The description of results are as follow

Table 1. Result of Variables

\begin{tabular}{|c|c|c|c|c|c|c|c|c|}
\hline \multicolumn{9}{|c|}{ VARIABLES } \\
\hline \multicolumn{3}{|c|}{ Personality (X1) } & \multicolumn{3}{|c|}{$\begin{array}{l}\text { Transformational Leadership } \\
\text { (X2) }\end{array}$} & \multicolumn{3}{|c|}{ Job Engagement (X3) } \\
\hline Indicators & Mean & \multirow{6}{*}{4.30} & Indicators & Mean & \multirow{6}{*}{4.26} & Indicators & Mean & \multirow{6}{*}{4.23} \\
\hline $\mathrm{X} 1.1$ & 4.40 & & $\mathrm{X} 2.1$ & 4.24 & & X3.1 & 3.81 & \\
\hline $\mathrm{X} 1.2$ & 4.32 & & $\mathrm{X} 2.2$ & 4.23 & & X3.2 & 4.47 & \\
\hline $\mathrm{X} 1.3$ & 4.11 & & $\mathrm{X} 2.3$ & 4.32 & & X3.3 & 4.17 & \\
\hline $\mathrm{X} 1.4$ & 4.43 & & $\mathrm{X} 2.4$ & 4.23 & & X3.4 & 4.26 & \\
\hline $\mathrm{X} 1.5$ & 4.24 & & $\mathrm{X} 2.5$ & 4.29 & & $\mathrm{X} 3.5$ & 4.44 & \\
\hline \multicolumn{3}{|c|}{ Organizational Commitment (Y1) } & \multicolumn{3}{|c|}{ OCB (Y2) } & \multicolumn{3}{|c|}{ Performance (Y3) } \\
\hline Indicators & Mean & & Indicators & Mean & & Indicators & Mean & \\
\hline Y1.1 & 4.39 & \multirow{5}{*}{4.10} & Y2.1 & 4.04 & \multirow{5}{*}{4.19} & Y3.1 & 4.49 & \multirow{5}{*}{4.36} \\
\hline Y1.2 & 3.97 & & Y2.2 & 4.01 & & Y3.2 & 4.29 & \\
\hline Y1.3 & 3.98 & & Y2.3 & 4.28 & & Y3.3 & 4.41 & \\
\hline Y1.4 & 4.03 & & Y2.4 & 4.30 & & Y3.4 & 4.13 & \\
\hline Y1.5 & 4.11 & & Y2.5 & 4.32 & & Y3.5 & 4.49 & \\
\hline \multicolumn{3}{|c|}{ Motivation (Z1) } & \multicolumn{3}{|c|}{ Organizational Culture (Z2) } & & & \\
\hline
\end{tabular}




\begin{tabular}{|c|c|c|c|c|c|}
\hline Indicators & Mean & & Indicators & Mean & \\
\hline Z1.1 & 4.41 & \multirow{5}{*}{4.31} & $\mathrm{Z} 2.1$ & 4.37 & \multirow{5}{*}{4.28} \\
\hline Z1.2 & 4.29 & & $\mathrm{Z} 2.2$ & 4.31 & \\
\hline Z1.3 & 4.32 & & $\mathrm{Z} 2.3$ & 4.23 & \\
\hline Z1.4 & 4.40 & & $\mathrm{Z} 2.4$ & 4.21 & \\
\hline Z1.5 & 4.12 & & $\mathrm{Z} 2.5$ & 4.30 & \\
\hline
\end{tabular}

Table 2. Validity Test Result

\begin{tabular}{|c|c|c|c|c|c|c|c|c|}
\hline \multicolumn{9}{|c|}{ Validity Test } \\
\hline \multicolumn{3}{|c|}{ Personality (X1) } & \multicolumn{3}{|c|}{$\begin{array}{c}\text { Transformational Leadership } \\
\text { (X2) }\end{array}$} & \multicolumn{3}{|c|}{ Job Engagement (X3) } \\
\hline Indicators & F.Loading & \multirow{6}{*}{$\begin{array}{l}\geq 0.5 \\
\text { Valid }\end{array}$} & Indicators & F.Loading & \multirow{6}{*}{$\begin{array}{l}\geq 0.5 \\
\text { Valid }\end{array}$} & Indicators & F.Loading & \multirow{6}{*}{$\begin{array}{l}\geq 0.5 \\
\text { Valid }\end{array}$} \\
\hline $\mathrm{X} 1.1$ & 0,662 & & $\mathrm{X} 2.1$ & 0,725 & & $\mathrm{X} 3.1$ & 0,634 & \\
\hline $\mathrm{X} 1.2$ & 0,678 & & $\mathrm{X} 2.2$ & 0,724 & & X3.2 & 0,727 & \\
\hline $\mathrm{X} 1.3$ & 0,652 & & $\mathrm{X} 2.3$ & 0,700 & & X3.3 & 0,733 & \\
\hline $\mathrm{X} 1.4$ & 0,666 & & $\mathrm{X} 2.4$ & 0,698 & & X3.4 & 0,703 & \\
\hline$X 1.5$ & 0,621 & & $\mathrm{X} 2.5$ & 0,702 & & $\mathrm{X} 3.5$ & 0,721 & \\
\hline \multicolumn{3}{|c|}{ Organizational Commitment (Y1) } & \multicolumn{3}{|c|}{ OCB (Y2) } & \multicolumn{3}{|c|}{ Performance (Y3) } \\
\hline Indicators & F.Loading & & Indicators & F.Loading & & Indicators & F.Loading & \\
\hline Y1.1 & 0,625 & \multirow{5}{*}{$\begin{array}{l}\geq 0.5 \\
\text { Valid }\end{array}$} & Y2.1 & 0,575 & \multirow{5}{*}{$\begin{array}{l}\geq 0.5 \\
\text { Valid }\end{array}$} & Y3.1 & 0,655 & \multirow{5}{*}{$\begin{array}{l}\geq 0.5 \\
\text { Valid }\end{array}$} \\
\hline Y1.2 & 0,688 & & Y2.2 & 0,657 & & Y3.2 & 0,722 & \\
\hline Y1.3 & 0,738 & & Y2.3 & 0,666 & & Y3.3 & 0,701 & \\
\hline Y1.4 & 0,702 & & Y2.4 & 0,693 & & Y3.4 & 0,680 & \\
\hline Y1.5 & 0,728 & & Y2.5 & 0,659 & & Y3.5 & 0,579 & \\
\hline \multicolumn{3}{|c|}{ Motivation (Z1) } & \multicolumn{3}{|c|}{ Organizational Culture (Z2) } & & & \\
\hline Indicators & F.Loading & & Indicators & F.Loading & & & & \\
\hline Z1.1 & 0,670 & \multirow{5}{*}{$\begin{array}{l}\geq 0.5 \\
\text { Valid }\end{array}$} & $\mathrm{Z2.1}$ & 0,607 & \multirow{5}{*}{$\begin{array}{l}\geq 0.5 \\
\text { Valid }\end{array}$} & & & \\
\hline Z1.2 & 0,684 & & $\mathrm{Z} 2.2$ & 0,769 & & & & \\
\hline Z1.3 & 0,761 & & $\mathrm{Z} 2.3$ & 0,817 & & & & \\
\hline Z1.4 & 0,716 & & $\mathrm{Z2.4}$ & 0,707 & & & & \\
\hline Z1.5 & 0,656 & & $\mathrm{Z2.5}$ & 0,740 & & & & \\
\hline
\end{tabular}

Table 3. Reliability Test Result

\begin{tabular}{|c|c|c|c|c|c|c|c|c|}
\hline \multicolumn{9}{|c|}{ Reliability Test } \\
\hline \multicolumn{3}{|c|}{ Personality (X1) } & \multicolumn{3}{|c|}{$\begin{array}{l}\text { Transformational Leadership } \\
\text { (X2) }\end{array}$} & \multicolumn{3}{|c|}{ Job Engagement (X3) } \\
\hline $\begin{array}{c}\text { Indicator } \\
\mathrm{s}\end{array}$ & $\begin{array}{l}\text { F.Loadin } \\
\mathrm{g}\end{array}$ & \multirow{6}{*}{$\begin{array}{c}\geq 0.7 \\
\text { Reliabl } \\
\text { e }\end{array}$} & $\begin{array}{c}\text { Indicator } \\
\mathrm{S}\end{array}$ & $\begin{array}{l}\text { F.Loadin } \\
\mathrm{g}\end{array}$ & \multirow{6}{*}{$\begin{array}{c}\geq 0.7 \\
\text { Reliabl } \\
\text { e }\end{array}$} & $\begin{array}{l}\text { Indicator } \\
\qquad \mathrm{s}\end{array}$ & $\begin{array}{l}\text { F.Loadin } \\
\mathrm{g}\end{array}$ & \multirow{6}{*}{$\begin{array}{c}\geq 0.7 \\
\text { Reliabl } \\
\text { e }\end{array}$} \\
\hline $\mathrm{X} 1.1$ & 0,682 & & $\mathrm{X} 2.1$ & 0,725 & & X3.1 & 0,634 & \\
\hline $\mathrm{X} 1.2$ & 0,678 & & $\mathrm{X} 2.2$ & 0,724 & & $\mathrm{X} 3.2$ & 0,727 & \\
\hline $\mathrm{X} 1.3$ & 0,652 & & $\mathrm{X} 2.3$ & 0,700 & & X3.3 & 0,733 & \\
\hline $\mathrm{X} 1.4$ & 0,666 & & $\mathrm{X} 2.4$ & 0,698 & & X3.4 & 0,703 & \\
\hline $\mathrm{X} 1.5$ & 0,671 & & $\mathrm{X} 2.5$ & 0,702 & & $\mathrm{X} 3.5$ & 0,721 & \\
\hline \multicolumn{3}{|c|}{$\begin{array}{l}\text { Organizational Commitment } \\
\text { (Y1) }\end{array}$} & \multicolumn{3}{|c|}{ OCB (Y2) } & \multicolumn{3}{|c|}{ Performance (Y3) } \\
\hline $\begin{array}{c}\text { Indicator } \\
\mathrm{s}\end{array}$ & $\begin{array}{c}\text { F.Loadin } \\
\mathrm{g}\end{array}$ & & $\begin{array}{c}\text { Indicator } \\
\mathrm{s} \\
\end{array}$ & $\begin{array}{l}\text { F.Loadin } \\
\mathrm{g}\end{array}$ & & $\begin{array}{c}\text { Indicator } \\
\mathrm{s}\end{array}$ & $\begin{array}{l}\text { F.Loadin } \\
\mathrm{g}\end{array}$ & \\
\hline Y1.1 & 0,625 & \multirow[b]{3}{*}{$\geq 0.7$} & Y2.1 & 0,575 & \multirow[b]{3}{*}{$\geq 0.7$} & Y3.1 & 0,775 & \multirow[b]{3}{*}{$\geq 0.7$} \\
\hline Y1.2 & 0,688 & & Y2.2 & 0,657 & & Y3.2 & 0,722 & \\
\hline Y1.3 & 0,738 & & Y2.3 & 0,666 & & Y3.3 & 0,701 & \\
\hline
\end{tabular}




\begin{tabular}{|c|c|c|c|c|c|c|c|c|}
\hline Y1.4 & 0,702 & \multirow{2}{*}{$\begin{array}{c}\text { Reliabl } \\
\mathrm{e}\end{array}$} & Y2.4 & 0,693 & \multirow{2}{*}{$\begin{array}{l}\text { Reliabl } \\
\text { e }\end{array}$} & Y3.4 & 0,680 & \multirow{2}{*}{$\begin{array}{l}\text { Reliabl } \\
\text { e }\end{array}$} \\
\hline Y1.5 & 0,728 & & Y2.5 & 0,659 & & Y3.5 & 0,689 & \\
\hline \multicolumn{3}{|c|}{ Motivation (Z1) } & \multicolumn{3}{|c|}{ Organizational Culture (Z2) } & & & \\
\hline $\begin{array}{c}\text { Indicator } \\
\mathrm{S} \\
\end{array}$ & $\begin{array}{c}\text { F.Loadin } \\
\mathrm{g}\end{array}$ & & $\begin{array}{c}\text { Indicator } \\
\mathrm{S} \\
\end{array}$ & $\begin{array}{c}\text { F.Loadin } \\
\mathrm{g}\end{array}$ & & & & \\
\hline Z1.1 & 0,670 & \multirow{5}{*}{$\begin{array}{c}\geq 0.7 \\
\text { Reliabl } \\
\text { e }\end{array}$} & Z2.1 & 0,607 & \multirow{5}{*}{$\begin{array}{c}\geq 0.7 \\
\text { Reliabl } \\
\text { e }\end{array}$} & & & \\
\hline $\mathrm{Z} 1.2$ & 0,684 & & $\mathrm{Z} 2.2$ & 0,769 & & & & \\
\hline $\mathrm{Z} 1.3$ & 0,761 & & $\mathrm{Z} 2.3$ & 0,817 & & & & \\
\hline $\mathrm{Z} 1.4$ & 0,716 & & $\mathrm{Z} 2.4$ & 0,707 & & & & \\
\hline $\mathrm{Z} 1.5$ & 0,656 & & $\mathrm{Z} 2.5$ & 0,740 & & & & \\
\hline
\end{tabular}

\subsection{Testing of SEM Assumptions}

Multivariate Normality

Multivariate CR is known to be -2.418 , the value is between -2.58 to +2.58 , so the data is multivariate normally distributed, or the assumption of multivariate normality is fulfilled.

Univariate Outlier

The Z-score value on all indicators is in the range of -3 to +3 , so that data is univariate which is not indicated as an outlier.

Multivariate Outlier

Chi-square table $=59.70$

The maximum value of Mahalobis d-square is known to be 48,701, this value is still smaller than 59,70, so there are also no outliers in the research data, so that all respondents (samples) can be used for analysis.

Table 4. Model Fit Test Results

\begin{tabular}{|c|c|c|c|}
\hline $\begin{array}{c}\text { Criteria of } \\
\text { goodness of fit }\end{array}$ & Requirement & Result & Explanation \\
\hline P value chi-square & $\geq 5 \%$ & 0,098 & Fit \\
\hline Cmin/df & $\leq 2,00$ & 1,094 & Fit \\
\hline RMSEA & $\leq 0,80$ & 0,022 & Fit \\
\hline GFI & $\geq 0,90$ & 0,880 & Marginal \\
\hline AGFI & $\geq 0,90$ & 0,857 & Marginal \\
\hline CFI & $\geq 0,90$ & 0,980 & Fit \\
\hline TLI & $\geq 0,90$ & 0,978 & Fit \\
\hline
\end{tabular}

\subsection{Results of Direct Effect Hypothesis Testing}

Result of direct effect testing are as follow

Table 5. Direct Effect Result

\begin{tabular}{|c|c|c|c|c|c|c|c|}
\hline Hip. & \multicolumn{3}{|c|}{ Relations between variables } & Coeff. & T count & $\mathrm{P}$ value & Explanation \\
\hline $\mathrm{H}_{1}$ & Personality $\left(\mathrm{X}_{1}\right)$ & $\rightarrow$ & $\begin{array}{c}\text { Organizational } \\
\text { Commitment }\left(\mathrm{Y}_{1}\right)\end{array}$ & 0,243 & 3,030 & 0,002 & Significant \\
\hline $\mathrm{H}_{2}$ & $\begin{array}{l}\text { Transformational } \\
\text { Leadership }\left(\mathrm{X}_{2}\right)\end{array}$ & $\rightarrow$ & $\begin{array}{c}\text { Organizational } \\
\text { Commitment }\left(\mathrm{Y}_{1}\right)\end{array}$ & 0,379 & 4,339 & 0,000 & Significant \\
\hline $\mathrm{H}_{3}$ & Job Engagement $\left(\mathrm{X}_{3}\right)$ & $\rightarrow$ & $\begin{array}{c}\text { Organizational } \\
\text { Commitment }\left(\mathrm{Y}_{1}\right)\end{array}$ & 0,425 & 4,802 & 0,000 & Significant \\
\hline $\mathrm{H}_{4}$ & Personality $\left(\mathrm{X}_{1}\right)$ & $\rightarrow$ & Performance $\left(\mathrm{Y}_{3}\right)$ & 0,007 & 0,084 & 0,933 & $\begin{array}{c}\text { Not } \\
\text { Significant }\end{array}$ \\
\hline $\mathrm{H}_{5}$ & $\begin{array}{l}\text { Transformational } \\
\text { Leadership }\left(\mathrm{X}_{2}\right)\end{array}$ & $\rightarrow$ & Performance $\left(\mathrm{Y}_{3}\right)$ & 0,180 & 2,028 & 0,043 & Significant \\
\hline $\mathrm{H}_{6}$ & Job Engagement $\left(\mathrm{X}_{3}\right)$ & $\rightarrow$ & Performance $\left(\mathrm{Y}_{3}\right)$ & 0,238 & 2,627 & 0,009 & Significant \\
\hline $\mathrm{H}_{7}$ & $\begin{array}{c}\text { Organizational } \\
\text { Commitment }\left(\mathrm{Y}_{1}\right)\end{array}$ & $\rightarrow$ & $\mathrm{OCB}\left(\mathrm{Y}_{2}\right)$ & 0,203 & 2,152 & 0,031 & Significant \\
\hline $\mathrm{H}_{8}$ & $\mathrm{OCB}\left(\mathrm{Y}_{2}\right)$ & $\rightarrow$ & Performance $\left(\mathrm{Y}_{3}\right)$ & 0,246 & 2,495 & 0,013 & Significant \\
\hline
\end{tabular}




\subsection{Moderate Variable Test}

The first step is to examine the effect of independent on dependents must be significant, and the moderator's influence on dependents must also be significant. The second stage is to test the effect of interaction on dependent must be significant, while the main influence that was previously significant, becomes insignificant.

Table 6. Moderate Phase I

\begin{tabular}{|c|c|c|c|c|c|c|}
\hline Explanation & \multicolumn{3}{|c|}{ Relations between variables } & Coeff. & $\begin{array}{c}\mathrm{P} \\
\text { value }\end{array}$ & Exp. \\
\hline \multirow{2}{*}{$\begin{array}{c}\text { Moderating } \\
\text { effect } \\
\text { Number-1 }\end{array}$} & $\begin{array}{l}\text { Organizational Commitment } \\
\left(\mathrm{Y}_{1}\right)\end{array}$ & $\rightarrow$ & $\mathrm{OCB}\left(\mathrm{Y}_{2}\right)$ & 0,218 & 0,021 & Significant \\
\hline & Motivation $\left(\mathrm{Z}_{1}\right)$ & $\rightarrow$ & $\mathrm{OCB}\left(\mathrm{Y}_{2}\right)$ & 0,306 & 0,002 & Significant \\
\hline \multirow{2}{*}{$\begin{array}{c}\text { Moderating } \\
\text { effect } \\
\text { Number-2 }\end{array}$} & $\mathrm{OCB}\left(\mathrm{Y}_{2}\right)$ & $\rightarrow$ & $\begin{array}{l}\text { Performance } \\
\left(\mathrm{Y}_{3}\right)\end{array}$ & 0,321 & 0,000 & Significant \\
\hline & Organizational Culture $\left(Z_{2}\right)$ & $\rightarrow$ & $\begin{array}{l}\text { Performance } \\
\left(\mathrm{Y}_{3}\right)\end{array}$ & 0,456 & 0,000 & Significant \\
\hline
\end{tabular}

The influence of the independent variable on the dependent and the effect of the moderator variable on the dependent, both are significant, so the testing of the moderation effect can be continued to stage 2

Table 7. Moderate Phase II

Testing the Effects of Interactions on Dependent Variables

\begin{tabular}{|c|c|c|c|c|c|c|}
\hline Hip. & Relations between & varia & & Coeff. & $\begin{array}{c}\mathrm{P} \\
\text { value }\end{array}$ & Exp. \\
\hline \multirow[t]{2}{*}{$\mathrm{H}_{9}$} & $\begin{array}{l}\text { Organizational Commitment } \\
\left(\mathrm{Y}_{1}\right)\end{array}$ & $\rightarrow$ & $\mathrm{OCB}\left(\mathrm{Y}_{2}\right)$ & 0,163 & 0,064 & Not Significant \\
\hline & Interaction $\mathrm{Z} 1 * \mathrm{Y} 1$ & $\rightarrow$ & $\mathrm{OCB}\left(\mathrm{Y}_{2}\right)$ & 0,006 & 0,017 & Significant \\
\hline \multirow{2}{*}{$\mathrm{H}_{10}$} & $\mathrm{OCB}\left(\mathrm{Y}_{2}\right)$ & $\rightarrow$ & $\begin{array}{l}\text { Performance } \\
\left(\mathrm{Y}_{3}\right)\end{array}$ & 0,230 & 0,003 & Significant \\
\hline & Interaction $\mathrm{Z} 2 * \mathrm{Y} 2$ & $\rightarrow$ & $\begin{array}{l}\text { Performance } \\
\left(\mathrm{Y}_{3}\right)\end{array}$ & 0,014 & 0,000 & Significant \\
\hline
\end{tabular}

Testing $\mathrm{H}_{9}$

The influence of the interaction variable on OCB $(\mathrm{Z} 1 * \mathrm{Y} 1 \rightarrow \mathrm{Y} 2)$ resulted in $\mathrm{p}$ value $<0.05$ so that it was significant, while the main influence $(\mathrm{Y} 1 \rightarrow \mathrm{Y} 2)$ resulted in $\mathrm{p}$ value $>0.05$ so that the previous significant influence was significant. This shows the moderating effect of motivation (Z1) on the influence of organizational commitment (Y1) on OCB (Y2).

The coefficient value of the interaction effect is 0.006 , this value is positive, meaning that motivation is proven to strengthen the influence of organizational commitment on OCB, so that $\mathrm{H}_{9}$ is accepted. The effect of organizational commitment on OCB will be stronger for employees with high work motivation.

$\mathrm{H}_{10}$ testing

The effect of the interaction variable on performance $(\mathrm{Z} 2 * \mathrm{Y} 2 \rightarrow \mathrm{Y} 3)$ resulted in $\mathrm{p}$ value $<0.05$ so that it was significant, while the main influence $(\mathrm{Y} 2 \rightarrow \mathrm{Y} 3$ ) also produced a $\mathrm{p}$ value $<0.05$ so that the main influence remained significant. This shows that there is no moderating organizational culture effect $(\mathrm{Z} 2)$ on the influence of OCB (Y2) on Performance (Y3), so that $\mathrm{H}_{10}$ is rejected. That is, the influence of OCB remains strong on performance, both in conditions of low organizational culture and in conditions of high organizational culture.

Regression equation results of the study

$\mathrm{Y} 1=0,243 \mathrm{X} 1+0,379 \mathrm{X} 2+0,425 \mathrm{X} 3$

$\mathrm{Y} 3=0,007 \mathrm{X} 1+0,180 \mathrm{X} 2+0,238 \mathrm{X} 3+0,246 \mathrm{Y} 2$

$\mathrm{Y} 2=0,203 \mathrm{Y} 1$

\section{Discussion}

The discussions of the results of research in accordance with hypotheses are as follow.

1. Personality influences Organizational Commitment Office Secretary of Private Company in Surabaya, this can be accepted, the results of data analysis show that Personality significantly influences Organizational Behavior 
with a regression coefficient of 0.243 . The results of this study support the research conducted by Farrukh et al (2017); Panaccio and Vandenberghe (2012); Spagnoli and Caetano (2012). Yang and Hwang (2014)

2. Transformational Leadership influences Organizational Commitment The Secretary of the Private Enterprise Office in Surabaya, this can be accepted, the results of data analysis show that Transformational Leadership has a significant effect on Organizational Commitment with a regression coefficient of 0.379 . The results of this study support the research conducted by Joo et al. (2012), Nguyen et al (2016), Nguyen et al (2016).

3. Job Engagement has an effect on Organizational Commitment The Secretary of the Private Enterprise Office in Surabaya is acceptable, data analysis shows that Job Engagement has a significant effect on Organizational Commitment with a regression coefficient of 0.425 . The results of this study support the research conducted by Basit (2019), Shamaa et al (2015), Agyemang and Ofei (2013), Prerana (2017)

4. Personality influences the performance of the Secretary of the Private Company Office in Surabaya, the results of data analysis show that Personality does not significantly influence Organizational Behavior with a regression coefficient of 0.007 . The results of this study reject the research conducted by Buil et al (2018), Widyasari et al (2007), Fiernaningsih (2017)

5. Transformational leadership influences the performance of the Secretary of the Private Company office in Surabaya, this is acceptable, the results of data analysis show that Transformational Leadership significantly influences performance with a regression coefficient of 0.18 . The results of this study support the research conducted by Buil et al. (2018), Elgelal and Noermijati (2014), Pratama (2015)

6. Job Engagement affects the Performance of the Secretary of the Private Enterprise Office in Surabaya, this can be accepted, the results of data analysis show that Job Engagement has a significant effect on performance with a regression coefficient of 0.238 . The results of this study support the research conducted by Anitha.J (2014), Sigianingrat. et al (2018), Dajani (2015)

7. Organizational commitment influences OCB Secretary of the Office of Private Companies in Surabaya this can be accepted, the results of data analysis show that Organizational Commitment influences OCB with a regression coefficient of 0.203 . The results of this study do not support the research conducted by Harwiki (2016) Organizational Commitment does not affect OCB, but the results of this study support the research conducted by Cheng et al (2011), Azan (2015)

8.OCB affects the Performance of the Secretary of the Private Company Office in Surabaya, this can be accepted, the results of data analysis show that OCB has an effect on Performance with a regression coefficient of 0.246. The results of this study support the research conducted by Mahasneh (2015); Chelagat et al (2015); Halim Dan Dewi (2018). Basu (2017). Sugianingrat et al. (2018)

9. Motivation as a variable Moderator of the influence of Organizational Commitment to OCB Office Secretary of Private Companies in Surabaya this can be accepted, in the results of data analysis shows that Motivation becomes a moderate variable the influence of Organizational Commitment on OCB with the moderator value of 0.006 . The results of this study support the research conducted by Pridar and Adamy (2018.

10. Organizational Culture as a moderator variable in the influence of OCB on the Performance of the Secretary of the Private Company Office in Surabaya. It turned out that the results of the study stated that Organizational Culture did not become a moderator variable on the effect of Organizational Citizenship Behavior on Performance where $\mathrm{p}$ value $<0.05$.

\section{Conclusion}

From the results of the processed data in this study the conclusions can be described as follows:

1. Personality, Transformational Leadership and Job Engagement significantly influence organizational commitment, this shows that organizational commitment or loyalty possessed by employees will increase and become stronger when supported by personalities who can be relied upon to behave and are supported by a very leadership style. inspiring for his subordinates besides being balanced by the attitude of employees as a depiction of emotions and feelings actively towards work activities carried out by someone in total.

2. Transformational leadership and Job Engagement significantly influence performance, this shows that leadership and job engagement owned by employees will increase and become stronger and more reliable in behaving and supported by a very inspirational leadership style for subordinates other than those complemented by attitude positive and productive employees.

3. Personality has no significant effect on performance, the findings of this study provide information that private company secretaries have fully realized the demands of their duties and personality (attitudes, behaviors and emotional strength / abilities) as professionals to distribute and store data for the company through data hardware and software.

4. Organizational commitment has a significant effect on Organizational Citizenship Behavior, this shows that high loyalty will form additional behavior beyond the capacity that must be done and is an excess of achievement for an employee and even supported or strengthened by the motivation he has.

5. OCB has an effect on performance, something reasonable because someone who has more capacity to achieve 
will increasingly influence his performance level and organizational culture as a moderator variable does not play a strong role in the influence of OCB on performance. So the organizational culture (strong or weak) has been firmly planted in employees as a professional secretary in other words, culture as a guide to behavior is known, understood and internalized and implemented consciously and correctly.

\section{Appendix: Indicators of Variables}

\section{Personality}

1. I prioritize hospitality when communicating with other people

2. In carrying out my duties and obligations in the company, always be careful

3. I always want to hold back emotions when there are personal problems or in the office

4. I always try to be comfortable when cooperating with anyone

5. I prioritize openness in accepting other people's opinions

\section{Transformational leadership}

1. Leaders always instill pride in their followers for the existence of the company

2. Leaders always inspire subordinates to achieve company goals

3.Peminpin always provides assistance in solving personal and official problems that arise in the organization

4. Leaders always provide training for the benefit of developing their subordinates

5. The leader always gives new knowledge to his subordinates

\section{Job Engagement}

1. I always enjoy my work under any circumstances

2. I do not limit work time if needed

3. I am able and try to complete the work properly and correctly

4. I always want to find other ways to produce maximum performance

5 . I really understand and appreciate my type of work

\section{Organizational Commitment}

1. I accept and recognize the values that exist in the company

2. I am sure that the company can protect my needs

3. I will not leave this company to move to another place of work

4. I already feel right working in this company to meet household needs.

5. I feel that this company provides a moral strength to pursue a career going forward

\section{Organizational Citizenship Behavior}

1. I do not limit the tasks given by the leader

2. I am always ready to help co-workers if they have difficulties in carrying out their duties

3. I am ready to work outside working hours if needed by the company

4. I am willing to give an opinion to the leader if there are problems outside of my duties

5. I am always ready to help companies when experiencing problems with the company's environment

\section{Motivation}

1. Paying is carried out fairly and objectively

2. Leaders always encourage their subordinates to develop themselves to employees

3. Providing awards to employees tailored to the performance of each

4. Social security is given in accordance with labor regulations

5. Subordinates are given the opportunity to participate in providing input in making decisions about problems that occur.

\section{Organizational culture}

1. Work regulations are carried out as needed

2. The company prioritizes employee honesty in carrying out their duties

3. The company always pays attention to the needs of ritual events in religious holidays.

4. Every employee must maintain the confidentiality of the company

5. Communication between supervisors working with subordinates runs harmoniously

\section{Performance}

1. Employees complete their tasks on time 
2. Employees do their work in accordance with the job description

3. Employees work according to their competencies

4. Employees never postpone their work assignments

5. Arrivals Employees at the company are always on time

\section{References}

Abdullah, Iqra; Omar, Rozeyta; Rashid ,Yahya. 2013. Effect of Personality on Organizational Commitment and Employees' Performance : Empirical Evidence from Banking Sector of Pakistan. Middle-East Journal of Scientific Research ISSN : 1990-9233. 18 (6) pp 759-766

Agyemang, Collins Badu; Ofei, Samuel Batchison. 2013. Employee Work Engagement and Organizational Commitment: A Comparative Study of Private and Public Sector Organizations in Ghana. European Journal of Business and Innovation Research. Vo.1 No.4 pp.20-23

Anitha.J. 2013 Determinants of employee engagement and their impact on employee performance.International Journal of Productivity and Performance Management. Vol63.No.3. pp.308-323

Apridar; Adamy,Marbawi. 2014. The Effect of Job Satisfaction and Organizational Commitment and Organizational Citizenship Behavior in BNI in The Working Area of Bank Indonesia Lhokseumawe. Emerald Reach Proceedings Series Vol.1. pp 1-5. Emerald Publishing Limited 2516-2853

Azan,Putra Gema. 2015. Pengaruh Organizational Commitment dan Professional Commitment Terhadap Organizational Citizenship Behavior Karyawan PT.Telkom. Pekanbaru. Jom.FEKOM Vol.2.No2 Hal.1-11 Faculty of Economics Riau University, Pekanbaru, Indonesia.

Bakker'A.B. 2010. An Evident base model of Job Engagement “ Current Direction in Psychology Sciences XX (4) PP.265269

Basit, Ameer A.2019. Examining how respectful engagement affects task performance and affective organizational commitment. The role of job engagement. Personnel Review. Emerald Publishing Limited 00483486. DOI10.1108/PR-02-2018-0050

Basu,Eeman. 2017. Impact of Organizational Citizenship Behavior on Job Performance in Indian Healthcare Industries.The mediating role of social capital.International Journal of Productivitry and Performnace Management.Vol.66 No.6. pp.780-796. Emerald Publishing Limited1741-0401

Buil,Isabel; Martinez,Eva; Matute,Jorge.2018.International Journal of $\quad$ Hospitality Management.https://doi.org/10.1016/j.ijhm.2018.06.014

Chelegat,Lelei Joy; Kiprop,Protus, Chepkwony; Kemboi,Ambrose. 2015. Effect of Organizational Citizenship Behavior on Employee Performance in Banking Sector,Nairobi County, Kenya. Vol4.No.4 pp 55-61

Cheng,Chang Chi; Chen,Meng; Shan,Tsai Meng. 2011. The Organizational Citizenship Behaviors and Organizational Commitments of Organizational members Influences the Effect of Organizational Learning. International Journal of Trade, Economics and Finance. ISSN:2010-023X Vol.2 No.1 pp 21-26

Dajani,Maha Ahmed,Zaki. 2015. The Impact of Employee Engagement on Job Performance and Organizational Commitment in The Egyptian Banking Sector. Journal Business and Management Science Vol.3 No.5 pp. 138-147

Elgelal,Kamel Shaleh Khalifa; Noermijati. 2014. The Influences of Transformational Leaderships on Employees Performance (A Study of the Economics and Business Faculty Employee at University of Muhammadiyah Malang. Asia-Pasific Management and Business Applications Vol.3 No.1 pp.48-66

Farrukh,Muhammad; Ying,Chong Wei; Mansori,Shaheen. 2017. Organizational Commitment: an Empirical Analysis of Personality Traits. Journal of Work-Applied Management Vol.9 No.I pp. 18-34

Ferdinand,Augusty. 2014. Metode Penelitian Manajemen,Pedoman Penelitian Untuk Penulisan Skripsi, Tesis dan Desertasi Ilmu Manajemen. Badan Penerbit Universitas Diponegoro.

Fiernaningsih,Nilawati. 2017. Pengaruh Kepribadian Terhadap Kinerja Karyawan Hotel Elresas Lamongan. Jurnal Administrasi dan Bisnis. Vol.11 No.2 hal.221-231. ISSN1978-726X

Gathungu,Edith W.M; Iravo,Mike A.; Namusonge.G.S. 2015. Transformasional Leadership and Employee's Commitmen: Empirical Review. IOSR-Journal of Humanities And Social Science (IOSR-JHSS) e-ISSN:2279-0837. Vol.20 Issue 7.Ver II pp 01-07

Halim,Ayu Nathaniah; Dewi, Maria Brigitta. 2018. Analisa Pengaruh Organizational Citizenship Behavior Terhadap Kinerja Karyawan Hotel Bintang 3 di Surabaya. Jurnal Hospitality dan Manajemen Jasa Vol.6 No.2 Hal 183 - 196; Manajemen Perhotelan.Fakultas EkonomiUniversitas Kristen Petra Surabaya.

Harwiki,Wiwik. 2016. The Impact of Servant leadership on Organization Culture, Organizational Commitment, Organizatioanal Citizenship Behavior (OCB) and Employee Performance in Women Cooperatives. Procedia-Social Behavioral Sciences. 219(2016) pp283-290

Hughes,Richad L; Ginnet,Robert C; Curphy,Gordon J.2012. Leadership. Memperkaya Pelajaran dari Pengalaman Edisi terjemahan Penerbit Salemba Empat Jakarta

Joo,Baek Kyoo; Yoon,Hea Jun; Jeung,Chang Wook. 2012. The effect of core self-Evaluations and Transformational 
Leadership on Organizational Commitment. Leadership \& Organizational Development Journal.Vol33 No.6 pp. 564-582.

Koesmono,Teman. 2016. Mengelola Sumber Daya Manusia Perusahaan. Indomedika Pustaka Yogyakarta.

Mahasneh-Al,Muhammad A.. 2015. The Impact of Organizational Citizenship Behavior on Job Performance at Greater Amman Municipality. European Journal of Business and Management. ISSN 2222-1905 (Paper) ISSN 2222-2839 (online) Vol.7 No.36 pp 108-118

McShane,Steven L; Glinov, Mary Ann Von. 2003. Organizational Behavior: Emerging, Realities for the Workplacer Revolution. McGrawhill.Irwin

Mondy,Wayne. 2008. Manajemen Sumber Daya Manusia Edisi kesepuluh Penerbit Erlangga.Jakarta

Moorhead, Gregory; ; Griffin,Ricky W. 2010. Perilaku Organisasi, Manajemen Sumber Daya Manusia dan Organisasi. Edisi terjemahan. Penerbit Salemba Empat Jakarta

Nguyen,Thi Thu; Mia,Lokman; Winata,Lanita; Chong,Vincent K. 2016. Effect of transformational leadership style and management control system on magerial performance. Journal of Business Research. JBR.09232 No of page 12

Paccio,Alexandra; Vandenberghe,Christian. 2012. Five Factor Model of Personality and Organizational Commitment: The mediating Role of Positive and Negative Affective States. Journal of Vocational Behavior 80 (2012) pp647-658

Pratama,Gilang. 2015. Effect Transformational Leadership Towards Employee's Performance Through Job Satisfaction and Moderated By Culture. Economic Faculty, Esa Unggul University. Jakarta Indonesia. pp.1-8

Prerana. 2017. Effect of Employee Engagement on Organizational Commitment. Indian Journal of Commerce \& Management Studies ISSN: 2249-0310 EISSN: 2229-5674.DOI :10.18843/ijcms/v8i2/14

Rahmawati,Ike Kusdyah .2008. Manajemen Sumber Daya Manusia Penerbit Andy Yogyakarta.

Robbins, Stephen P; Judge,Timothy.A. 2015. Perilaku Organisasi. Penerbit Salemba Empat Jakarta

Sani, Achmad; Maharani,Vivin. 2012. The Impacts of Transformasional Leadership and Organizational Commitment on Job Performance with The Among Lectures of Faculty in Rhe Islamic Maulana Malik Ibrahim Malang University: The mediating Effects of Organizational Citizienship Behavior. International Journal of Academic Research Vo;.4 No.4 pp 1-6

Seed,Rashid; Hashmi,Arshia; Lodhi,Rab Nawaz; Ahmad, Moeed; Arshad,Hafiz Muhammad; Achmad,Muhammad Azeem. 2013. The Effect of Transformasional Leadership on Organizational Commitmen With a Mediating Effectof Psichological Empowerment. Journal of Basic and Applied Scientific Research. ISSN : 2090-4304 3(6) pp. 28-36

Shamaa, Rasha Abu; Rabayah,Wafaa A.Al; Khasawneh,Rawan T. 2015. The Effect of Job Satisfaction and and work Engagement on Organizational Commitment. The UIP Journal of Organizational Behavior Vo.XIV No.4 pp 7-27

Spagnoli,Paola; Caetano,Antonio. 2012. Personality and Organizational Commitment. The Mediating Role of Job Satisfaction During Socialisation. Career Development International Vol.17 No.3 pp 255-275.

Sugianingrat, ida Ayu Putu Widani; Widyawati,Sapta Rini; Costa,Carla Alexandra de Jesus; Ximenes,Mateus; Piedede,Salustiano Dos Reis; Sarmawa,Wayan Gede. 2018 The Employee engagement and OCB as Mediating on Employee Performance. International Journal of Productivity and Performance Management. Emerald Publishing Limited 1741-0401.DOI10.1108/IJPPM-03-2018-0124

Sugiyono. 2010. Metode Penelitian Kuantitatif, Kualitatif dan R\& D Penerbit Alfabeta. Bandung

Yang,Cheng Liang; Hwang,Mark. 2014. Personality traits and Simultaneous reciprocal influences between job performance and job satisfaction. Chinese Management Studies Vol.8.No.1 pp.6-26 Emerald group Publishing Limited.1750614X dan Daerah Istimewa Yogyakarta.

Widyasari,Ratna; Syahlani, Suci Paramitasari; Santoso, Krisnha Agung. 2017. Pengaruh Kepribadian Terhadap Kinerja Karyawan Berpendidikan Tinggi : Analisis Pada Perusahaan Peternakan di Jawa Tengah. Kinerja Vol11 No.1 